I was actually worried that I wouldn't like the class because I have not particularly enjoyed past history classes. The course has changed my feelings dramatically. If I do not end up working in New York, I will research the history of education in the state I end up working in. The course has shown me the relevance of the history of education, within each state, to present-day education.

Despite this student's claim, I do not really know if she will transfer her historical competencies to her future career. Students complete exit surveys about their course experiences when they leave our program and some complete surveys a year after graduation, but the questions are too general for me to ascertain whether the transfer of historical competencies to teaching practice actually happens. Nor do I really know if students are able to apply their ability to consider multiple points of view when they are teaching students from diverse racial, ethnic, socioeconomic, and gendered backgrounds. However, this pedagogical case study suggests that these are the kinds of questions that should inform my future scholarship of teaching and learning.

\title{
Civil Rights, Educational Inequality, and Transnational Takes on the U.S. History Survey
}

\author{
Laura K. Muñoz
}

\section{Course: U.S. History Since 1865 (survey course) \\ Institution: Texas A\&M University-Corpus Cbristi}

In Mexicans in the Making of America, historian Neil Foley reconceptualizes Manifest Destiny, not as the glorious westward push of European Americans, but as their arrival on the doorstep of Mexican America. ${ }^{1} \mathrm{He}$ argues that the United States came to Mexico, and we must reimagine

\footnotetext{
Laura K. Muñoz is an associate professor of history at Texas A\&M University-Corpus Christi and a former National Academy of Education/Spencer Postdoctoral Fellow. She specializes in the history of race, gender, and education in the Southwest. Thank you to Natasha M. Crawford, Veronica Guzman Hays, and an endowment from the Paul and Mary Haas Foundation.
}

'Neil Foley, Mexicans in the Making of America (Cambridge, MA: Belknap Press of the Harvard University Press, 2014). 
this moment as an entry into an established New World where negotiation, conquest, and possession were already in play among various peoples and nations. The diversity of this nineteenth-century world is often absent in the ways that we have been trained to teach students in our first-year courses, and this absence, in turn, extends into our twentieth-century and contemporary discussions of race and race relations where binary comparisons dominate. Using educational and legal case studies from a variety of communities has allowed me to expand analyses in the U.S. history survey and to broaden students' conceptualizations from a singular white or binary black/white experience into a unified multilingual, multicultural, and transnational America. More importantly, this shift creates space for diverse groups of students to reconsider their own historical significance in the U.S.-Mexico borderlands and the relevance of local historical narratives in the scope of American history.

As a citizen scholar of the American West interested in questions about Latina/o experience, especially education as a modern civil right, my goal is to expand students' notions of "America" and "Americans," and to explore with them how questions of race and place, citizenship and nation, and equality and opportunity are inextricably linked across generations. Opting for undercoverage, analysis, and interpretation, I weave through the survey a series of histories about American Indians, Asian Americans, and Latinos in order to illustrate critical connections across time and place, such as the passage of the Fourteenth Amendment and its impact across the nation through the long civil rights movement beyond Brown v. Board of Education and the new millennium. ${ }^{2}$ In fact, case studies about civil rights and educational inequality - to which many of my first-generation, working-class, and immigrant students become highly attuned-allow me to demonstrate how modern freedom struggles since Reconstruction transpired as longer, complicated activisms still shaping a history of the present. My approach emerges from my experiences teaching large-lecture survey courses in the firstyear learning communities at my Hispanic-Serving Institution (HSI), which is also located in my hometown and is the alma mater of many of my relatives, as well as from my participation in the 2010 rewrite of the Texas social studies standards, where an emphasis on exceptionalism often outweighed historical truth. ${ }^{3}$

In an effort to push my students and "the field as a whole to become more aware and articulate about how a western/southwest perspective

\footnotetext{
${ }^{2}$ Brown v. Board of Education, 347 U.S. 483 (1957).

${ }^{3}$ Laura Muñoz and Julio Noboa, "Hijacks and Hijinks on the U.S. History Review Committee," in Politics and the History Curriculum: The Struggle Over Standards in Texas and the Nation, ed. Keith A. Erekson (New York: Palgrave Macmillan, 2012), 41-60.
} 
... alters our narrative," I begin the U.S. history survey with Standing Bear v. Crook (1879), a federal habeas corpus case that resulted from the death of Bear Shield, the teenage son of the Ponca leader Standing Bear. ${ }^{4}$ This case is the legal foundation for Indian citizenship and civil rights. ${ }^{5}$ Standing Bear was the first American Indian to sue the government in a federal court, and the first to secure his freedom as "a person" under U.S. law, specifically the Fourteenth Amendment. ${ }^{6}$ Standing Bear won his right to live freely outside of Indian territory and to return to his northeastern Nebraska homeland to bury his son. Standing Bear's selfdefense had everything to do with our national beliefs about education. Before his death, Bear Shield attended school, served as a translator for his father and other Ponca leaders, and often read the Bible at public gatherings. ${ }^{7}$ We can extrapolate Bear Shield's educational profile by considering the history of Indian boarding schools and by examining the life of his contemporary, Susette "Bright Eyes" La Flesche Tibbles. A regarded linguist and the daughter of an Omaha chief, Bright Eyes acted as Standing Bear's translator at court and later during an East Coast speaking tour. ${ }^{8}$ She learned English at the Presbyterian mission boarding school on her Omaha Reservation; the school was funded equally by the Presbyterian Board of Foreign Missions and the tribal government. ${ }^{9}$ Seeking higher education, she attended the Elizabeth Institute for Young Ladies in New Jersey and returned as teacher and principal of the reservation school. With Bright Eyes' voice, Standing Bear persuasively argued for American Indian humanity. He said, "This hand is not the color of yours, but if I pierce it, I shall feel pain. If you pierce your hand, you also feel pain. The blood that will flow from mine will be of the same color as yours. I am a man. The same God made us both." 10

\footnotetext{
${ }^{4}$ Nancy Beadie, e-mail correspondence to author, May 5, 2015; Joe Starita, I Am a Man: Standing Bear's fourney for Fustice (New York: St. Martin's Press, 2008).

${ }^{5}$ United States ex rel. Standing Bear v. Crook, 25 F. Cas. 695 (C.C.D. Neb. 1879) (No. 14, 891); and Joe Starita, "The Case of Standing Bear: Establishing Personhood under the Law," Court Review: The Fournal of the American Fudges Association, Paper 287 (2009), 10.

${ }^{6}$ Starita, I Am a Man, 144, 157.

7Starita, I Am a Man, 129, 141; “Chief Standing Bear," U.S. Department of the Interior, National Park Service, http://www.nps.gov/mnrr/learn/historyculture /standingbear.htm; and "Standing Bear v. Crook," U.S. Department of the Interior, National Park Service, http://www.nps.gov/mnrr/learn/historyculture/upload/ Standing\%20Bear.pdf.

${ }^{8}$ Starita, I Am a Man, 177-78; Dorothy Clarke Wilson, Bright Eyes, the Story of Susette La Flescbe, an Omaba Indian (New York: McGraw-Hill Book Company, 1974).

'Thomas P. Myers, The Birtb and Rebirth of the Omaba (Lincoln: University of Nebraska State Museum, 1992), part of the online collection "Omaha Indian Heritage," http://omahatribe.unl.edu/etexts/oma.0001/.

${ }^{10}$ Starita, I Am a Man, 151.
} 
The individual histories of Standing Bear, Bear Shield, and Bright Eyes illuminate the careful decisions each made as Manifest Destiny reshaped their worlds. For example, the Omaha and the Ponca nations conceded to Americanization as a strategy for cultural survival. Bright Eyes' work as a teacher and cultural broker profoundly influenced the American public's growing sympathy for American Indian sovereignty. She made it possible for Standing Bear to speak and be understood, and for Indians and whites to communicate their concerns to one another. In 1880, she even testified to the U.S. Congress on Standing Bear's behalf. ${ }^{11}$ These shared biographies provide students with a glimpse of the negotiation that American Indians encountered as they mastered the cultural and linguistic competencies to excel in Indian and white worlds. Many of the college students, surprisingly, grow to defend American Indian sovereignty, particularly Standing Bear's legal strategy, as they critique the drastic assimilation demanded of Indian youth.

Biographies also allow students to consider how change over time-as personal, cultural, or national-is embodied within the life trajectory of the historical actor. Whether teaching at an HSI or at a Research I institution, I use positionality as a pathway for emphasizing America's plurality. I want students to wonder how each of us is part of this dialogue. For instance, I ask students to use "selfies" to write about historical significance in their own lives, and then I ask them to apply this analysis in class discussions to historical images. I also model this self-inquiry as a way to provide context for students to make theoretical leaps toward broader constructions of America. I am aware that many students are curious about how I became their professor. Teaching them how to incorporate me-a prieta (dark) Chicana lesbian-into their spectrum of "professor" is one of the first steps in getting them to reconsider the scripts embedded within American history. I start by teaching them how to say my last name (moon-Yōs) and then introduce them to my ninety-five-year-old maternal grandmother, María Cabrera Cantú, who was born in 1920 Corpus Christi and attended its Mexican school until the sixth grade. To contribute to her family's income, María sold food door-to-door during the Great Depression until she was old enough, and perceived by Anglos to be Americanized enough, to clerk in a five-and-dime store. Her personal desire to be educated became her children's and grandchildren's desires. When I lingered in graduate school, she called me up to tell me: "Please finish the PhD before I die!" The students always laugh and this moment inspires a

\footnotetext{
"Susette LaFlesche [Tibbles] (Inshta Theamba, Bright Eyes), "From Testimony before the US Senate on the Removal of the Ponca Indians" (1880), in Native American Women's Writing: An Antbology, c. 1800 -1924, ed. Karen L. Kilcup (Malden, MA: Blackwell Publishers, 2000), 172-74.
} 
classroom rapport based on authenticity. The takeaway is that race, class, gender, and sexuality are actually user-friendly lenses for examining American history. By placing biography (mine, theirs, or Standing Bear's) alongside national historical contexts, students consider how individual experience matters and is shaped by larger structures. This interpersonal dynamic also creates a safe space for students to recognize that I am serious not only about revisioning American history, but incorporating their narratives too.

Embracing positionality to teach historical context further gives me the intellectual authority to crack open the traditional approach to the U.S. survey. When I teach Reconstruction, Standing Bear provides an important background for analyzing the racialized separation and segregation that occurred across the entire nation. I use discussions of the Fourteenth Amendment, its promises of birthright and naturalized citizenship, and the emergence of the Freedmen's Schools alongside Ponca history and the California example of Tape v. Hurley (1885), which challenged Chinese children's public school segregation. ${ }^{12}$ In 1885, Mary Tape sued Principal Jennie Hurley for refusing to admit Tape's American-born daughter Mamie to the Spring Valley School in San Francisco. Even though the California Supreme Court ruled in Tape's favor, the state continued to support Chinese, and later Korean and Japanese, school segregation. This accommodation to racial separatism led in part to the international conflict that emerged in the 1907-1908 Gentleman's Agreement that limited Japanese immigration into the United States, but also partially corrected Asian school segregation by allowing Japanese American children to attend white public schools. ${ }^{13}$ This extended inquiry allows students to build a new intellectual scaffolding about the construction of citizenship; that it is produced, conjured, and negotiated in a specific historical moment. For example, students compare the citizenship of Standing Bear, the Tape family, and the Freed People. I ask them to consider how the U.S. government (or we the people) differentiates birthright citizenship from naturalization, how this difference limits or extends rights to certain people, and how these inclusions and exclusions affect group participation in American society. One student said that thinking about

${ }^{12}$ Tape v. Hurley, 66 Cal. 473, 6, 12 (1885).

${ }^{13}$ Bill Ong Hing, "The Fight to Go to S.F. Public Schools," http://www.irwinator.com/126/wdoc147.htm; Mae M. Ngai, "History as Law and Life: Tape v. Hurley and the Origins of the Chinese American Middle Class," in Cbinese Americans and the Politics of Race and Culture, ed. Sucheng Chan and Madeline Y. Hsu (Philadelphia, PA: Temple University Press, 2008), 62-90; and Mae Ngai, The Lucky Ones: One Family and the Extraordinary Invention of Chinese America (Princeton, NJ: Princeton University Press, 2012). 
citizenship in this way allowed him to embrace solidarity in these multiple quests for equality.

This framework also prepares students to consider deeper questions about racial diversity and the often parallel struggles of people of color vis-à-vis white privilege and immigrants vis-à-vis citizenship privilege. For example, understanding that Jim Crow is as much a Western tradition as a Southern one, students recognize the emergence of Juan Crow, the de facto separation from whites that marked the lives of Mexican immigrants, Mexican Americans, and U.S. Latinos. In a recent study by the National Park Service, historian Victoria-María MacDonald provides the five hundred twenty-four years context for understanding the sites and locales where Latino education emerged. ${ }^{14}$ Taken together with Richard Valencia's Chicano Students and the Courts, students can chart one of the thirty-five school desegregation court cases that parents and community organizations filed on behalf of their children between 1925 and $1985 .{ }^{15}$ By tracing these places and events, students gain a clearer measure of the centuries-long challenges to racialization and language separation Latinos faced in public schools and accommodations before and after the 1954 Brown decision. The earliest lawsuit, Romo v. Laird (1925), for example, immediately places the question of Jim Crow and Juan Crow side by side as an Arizona superior court contemplates whether Mexicans are subject to the "separate but equal" standard of Plessy v. Ferguson (1896). ${ }^{16}$

Excerpts from new works, such as film documentaries The Children of Giant (2015) and Stolen Education (2013), the box office hit Walkout! (2006), and the oral history Blowout! Sal Castro and the Chicano Struggle for Educational fustice (2014), also illustrate subtractive curriculums and conditions at segregated Mexicans schools as late as the 1970 s. $^{17}$ For example, in The Children of Giant, director Hector Galán visits

${ }^{14}$ Victoria-María MacDonald, "Demanding Their Rights: The Latino Struggle for Educational Access and Equity," in American Latinos and the Making of the United States: $A$ Tbeme Study (Washington, DC: National Park System Advisory Board, 2013), online through the National Park Service at http://www.nps.gov/ history/heritageinitiatives/latino/latinothemestudy/pdfs/Education_final_web.pdf.

${ }^{15}$ Richard Valencia, Cbicano Students and the Courts: The Mexican American Legal Struggle for Educational Equality (New York: New York University Press, 2008).

${ }^{6}$ Laura K. Muñoz, "Romo v. Laird: Mexican American School Segregation and the Politics of Belonging in Arizona," Western Legal History 26, nos. 1-2 (2013): 99-134; Laura K. Muñoz, "Separate but Equal?: A Case Study of Romo v. Laird and Mexican American Education," OAH Magazine of History 15, no. 2 (Winter 2001): 28-35.

${ }^{17}$ The Cbildren of Giant, directed and produced by Hector Galán (2015; Burbank, CA: Latino Public Broadcasting, 2015), DVD; Giant, directed by George Stevens (1956; Hollywood, CA: Warner Brothers, 2005), DVD; Walkout!, directed by Edward James Olmos (2006; New York: HBO Studios, 2009), DVD; Mario T. García and Sal Castro, Blowout! Sal Castro and the Cbicano Struggle for Educational fustice (Chapel Hill: University of North Carolina Press, 2014). 
the west Texas town of Marfa that served as the film set for the 1956 movie Giant starring Elizabeth Taylor, Rock Hudson, and James Dean. Galán, whose father attended a segregated Mexican school, interviewed the former child stars who appeared as film extras and who attended Marfa's segregated Blackwell School. These children, now adults, recount the day they buried "Mr. Spanish" under the American flag in a 1954 school assembly described as "The Last Rights of Spanish Speaking." The teachers hosted a mock funeral and interred Mr. Spanish in a small wooden casket that contained a Spanish dictionary and scraps of papers with the scribbled words "I will not speak Spanish" written by the students. The casket remained buried until 2012, when the school alumni association disinterred it in a reunion celebration to recognize the former segregated Mexican school as a Texas historical landmark.

Learning this unfamiliar history initially stuns students, especially those with Spanish-language heritage who wonder why some of us speak "English only" or who question whether they have the right to attend or the ability to succeed at university. But through comparative explorations of the civil rights movements and school segregation, students learn how to contextualize the multiethnic, multiracial challenges to white supremacy. I help guide them through these conversations by lecturing about links between the people, their politics, and their lawsuits. For example, in the federal court cases Méndez et al. $v$. Westminster ISD et al. (1947) and Cisneros et al. v. Corpus Cbristi ISD (1970), I explain how "intergroup unity" led to the massive school desegregation victories that changed public schools and how Americans talked about race and citizenship. ${ }^{18}$ When a California school refused admission to the Méndez children, their parents sought counsel of Jewish attorney David Marcus, and received legal support from national civil rights groups, including the National Association for the Advancement of Colored People (NAACP), the American Civil Liberties Union (ACLU), the Japanese American Citizens League (JACL), and the League of United Latin American Citizens (LULAC), which took an active role in establishing the class action lawsuit against four school districts. Each organization wrote amicus briefs supporting the Méndez family, and these briefs formed the legal foundation for arguing the social and

${ }^{18}$ Toni Robinson and Greg Robinson, "Méndez v. Westminster: Asian-Latino Coalition Triumphant?," Asian American Law Fournal 10, no. 2 (2003): 161-83; Vicki L. Ruiz, "Tapestries of Resistance: Episodes of School Segregation and Desegregation in the Western United States," in From the Grassroots to the Supreme Court: Brown v. Board of Education and American Democracy, ed. Peter F. Lau (Durham, NC: Duke University Press, 2004), 44-67; Philippa Strum, Méndez v. Westminster: School Desegregation and Mexican-American Rights (Lawrence: University Press of Kansas, 2010); and Valencia, Cbicano Students and the Courts, 60. 
psychological effects children suffered as a result of segregation. ${ }^{19}$ For the first time in legal history, a federal district court considered social science evidence and applied it in the ruling. This judgment set the terms for federal school desegregation, first in the American West with the desegregation of California and Arizona public schools in 1947 and 1953 , respectively, and then nationally in the 1954 U.S. Supreme Court Brown decision. ${ }^{20}$

In South Texas, the failure of the Corpus Christi schools to heed the Brown decision led to mass protests in the 1960s and 1970s among youth and their parents inspired by the radicalization of the civil rights movements. Brown and black parents sued the Corpus Christi Independent School District (CCISD) in 1968 for failing to integrate and improve neighborhood schools. ${ }^{21}$ The parents accused the district of using the "white by law" classification of Mexican Americans to claim school integration in historically black and Latino neighborhoods. ${ }^{22}$ As Cisneros moved through the courts, a unique civic activism emerged that blended the traditional legal strategies of civil rights groups such as LULAC, the American G.I. Forum (AGIF), and the Mexican American Legal Defense and Education Fund (MALDEF), with the labor activism of the plaintiff parents who were members of the United Steel Workers of America, and with Chicano youth who emphasized "brown power" and movement tactics reminiscent of the 1968 East Los Angeles high school walkouts. ${ }^{23}$ For example, in 1972, AGIF leader Dr. Héctor P. García and Chicano youth led a sit-in and takeover of the CCISD offices, for which they were arrested. ${ }^{24}$ After years of appeals,

${ }^{19}$ Strum, Méndez v. Westminster, 138.

${ }^{20}$ Laura K. Muñoz, "Ralph Estrada and the War against Racial Prejudice in Arizona," in Leaders of the Mexican American Generation: Biograpbical Essays (Boulder: University Press of Colorado, 2015), 255-77; and Jeanne M. Powers and Lirio Patton, "Between Méndez and Brown: Gonzales v. Sbeely and the Legal Campaign against Segregation," Law and Social Inquiry 33, no. 1 (Winter 2008): 127-71.

${ }^{21}$ Guadalupe San Miguel Jr., Brown, Not White: School Integration and the Cbicano Movement in Houston (College Station: Texas A\&M University Press, 2001), 76-77; see also Guadalupe San Miguel Jr., "Let All of Them Take Heed": Mexican Americans and the Campaign for Educational Equality in Texas, 1910-1981 (Austin: University of Texas Press, 1987).

${ }^{22}$ Federal case law described Mexican Americans as "white by law" given the original citizenship status granted to Mexicans under the 1848 Treaty of Guadalupe-Hidalgo. See Ian Haney López, Wbite By Law: The Legal Construction of Race (New York: New York University Press, 2006).

${ }^{23}$ Garcia and Castro, Blowout!, 212-20.

${ }^{24}$ Daisy Wanda Garcia, "CCISD's Desegregation Struggles," Corpus Cbristi CallerTimes, 3 March 2012, accessed June 22, 2015 at http://www.caller.com/opinion/ columnists/ccisds-desegregation-struggle; Alan Lesoff, Wbere Texas Meets the Sea: Corpus Cbristi and Its History (Austin: University of Texas Press, 2015), 131; and Guadalupe San Miguel Jr., Cbicana/o Struggles for Education: Activism in the Community (College Station: Texas A\&M University Press, 2013), 26. 
the federal courts determined that the CCISD qualified as a "de jure segregated school system" where Mexican Americans as an "identifiable, ethnic minority" were "discriminated against as a class" alongside "Negro students." ${ }^{25}$ The court ordered the district to implement a desegregation busing plan in 1976, which was replaced in 1982 with a majority-to-minority transfer plan. The court oversight remained in place until 1997. After discovering how and why this local history matters in the scope of our national narratives, one student wrote in an exam that these examples convinced him that he could finish college.

Threading the first-year survey course with diverse educational and legal case studies helps students comprehend how the social, cultural, and political integration of their lifetime is wrought from combined struggles and successes. They also learn how this integration, especially in higher education, is constantly threatened and why college is insurmountable for many underrepresented students. Today, across our nation, several states have passed laws that ban undocumented students from attending our public universities and colleges. ${ }^{26}$ In these instances, immigrant children who are known as DREAMers (for the failed congressional legislation Development, Relief, and Education for Alien Minors or DREAM Act) or as DACAs (because they qualify for Deferred Action for Childhood Arrivals) are prohibited from enrolling at state and federally funded universities and/or from receiving in-state tuition rates. By law, Georgia's top five public universities deny admission and in-state tuition to qualified immigrant students who were educated in its own public schools. The American Historical Association (AHA) calls this "segregation based solely on . . . immigration status." ${ }^{27}$ As AHA President Vicki L. Ruiz explains, "these hardworking, ambitious young Americans have had no control over that status, just as their African American predecessors-also excluded from sectors of the state university system-had no control over their segregation."28 The struggle for educational equity lingers in our present, and teaching students this history as an integral element of the survey helps them to recognize not only the diversity of our nation, but also their duty to preserve the freedoms we have promised ourselves for generations.

${ }^{25}$ Cisneros v. Corpus Cbristi Independent School District, 324 F. Supp. 599 (1970).

${ }^{26}$ Zenen Jaimes Pérez, "Removing Barriers to Higher Education for Undocumented Students," policy report (Washington, DC: Center for American Progress, 2014), https://www.luminafoundation.org/files/resources/removing-barriersfor-undocumented-students.pdf.

${ }^{27}$ Vicki L. Ruiz to Board of Regents of the University System of Georgia, June 22, 2015, http://www.historians.org/Documents/A\%20Board\%20of\%20Regents \%20Letter\%20of\%20Protest\%20June\%202015.pdf.

${ }^{28} \mathrm{Ibid}$. 